DOI 10.2478/auseb-2020-0002

\title{
Corruption and Ease of Doing Business: Evidence from ECOWAS
}

\author{
Kamaldeen Ibraheem NAGERI, ${ }^{1^{*}}$ \\ Umar GUNU ${ }^{2}$ \\ $1^{*}$ Department of Banking and Finance, Al-Hikmah University, Ilorin, Nigeria \\ e-mail: nagerisuccess2000@yahoo.co.uk
}

2 Department of Business Administration, University of Ilorin, Ilorin, Nigeria e-mail: umargunu@gmail.com

\begin{abstract}
Corruption has a major impact on growth in low-income economies, while ease of doing business has a major impact on growth in developed countries. The study empirically examines the effect of corruption on ease of doing business. The study analyses unbalanced panel data of corruption rank, corruption score, control of corruption, and inflation, together with other economic and financial institutional factors and ease of doing business score for the period of 2004-2017. Results indicate that: corruption rank, inflation, and import have negative and significant effect on ease of doing business; corruption score, control of corruption, lending rate spread, and education (skill level) have positive and significant effect on ease of doing business; gross capital formation and population have insignificant negative effect on ease of doing business; export and gross domestic product have insignificant positive effect on ease of doing business. The random effect model is a consistent and most efficient model, indicating common mean value for ease of doing business for the dataset. The study recommends improved corruption scores, control of corruption, and ranks to encourage ease of doing business through monetary policy and infrastructural facilities.
\end{abstract}

Keywords: ease of doing business, corruption, panel data, ECOWAS JEL Classification: C23, D73, F42, M13

\section{Introduction}

Ease of doing business often has major impact on growth in developed countries, while corruption often has major impact on growth in low-income economies (Sunkanmi and Isola, 2014; Mongay and Filipescu, 2012). The National Bureau of Statistics (2017) reports that nearly one-third of Nigerians paid or were requested to 
pay a bribe when they had contact with public officials between June 2015 and May 2016. Anoruo and Braha, (2005) identify two views on the impact of corruption: the first one is that corruption is beneficial (aids the process of project approval efficiently), and the second one is that corruption is detrimental (increases the cost of business, induces uncertainty) to the economy. Therefore, corruption in low-income economies has attracted substantial attention among practitioners and academia as a result of its implication on economies.

Empirical investigation and analysis of corruption and ease of doing business are done independently, but there exist few studies on the effect of corruption on ease of doing business. Bribery as an indicator of corruption leads to infrastructural deficiency (Kenny, 2009); the analysis of corruption effects on investment growth indicates inconsistent findings across regions (Asiedu and Freeman, 2009). Ali and Isse (2003) opined that identifying the determinants of corruption will assist in the formulation of policies to reduce and check the negative effects of corruption. In the presence of laws and policies that make it extremely difficult for corrupt practices, in order to carry out international business, citizens resort to the "black market" to evade the legal system and transact business (Mongay and Filipescu, 2012). Thus, literature requires the assessment of the effects of corruption on ease of doing business in order not to promote the practice of corruption and not to make doing business more difficult for corporations.

Ease of doing business rankings attract high foreign direct investments (Jayasuriya, 2011), but Corcoran and Gillanders (2014) provide evidence that this effect is determined by the trading across border component of the ease of doing business. According to the Corruption Perception Index (CPI) report of Transparency International (TI) in 2016, the West African average corruption score was 31.7, marginally higher than the average sub-Saharan African average corruption score of 31. The West African average corruption score includes Cape Verde, which was the second best-rated African country, but thirteen West African countries were in the bottom half of the table and six were in the last quarter. Seven countries declined in the ranking compared to 2015 such as Mauritania and Ghana going down 30 and 16 places respectively. Corruption has always been at the heart of debates, campaigns, and elections in West Africa because it is a major problem in the sub-region. Therefore, since there is an agreement between West African states to facilitate and ease trading across the borders of member states, it is appropriate to examine corruption and ease of doing business in the sub-region.

Therefore, the objective of this study is to empirically examine the effect of corruption on ease of doing business. The existing arguments in the literature were taken into consideration, while data on corruption and ease of doing business were obtained from Transparency International and the World Bank Group for the sixteen (16) West African countries, which are: Benin, Burkina Faso, Cape Verde, Cote d'Ivoire, Gambia, Ghana, Guinea, Guinea Bissau, Liberia, Mali, Mauritania, 
Niger, Nigeria, Senegal, Sierra-Leone, and Togo. Mauritania is not a member of the Economic Community of West African States (ECOWAS) as the country withdrew her membership in 2000, but an Economic Partnership Agreement (EPA) signed with the European Union (EU) and flagged off in 2004 included Mauritania in the agreement, which was to establish a free trade area between Europe and West Africa (ECOWAS + Mauritania) in accordance with Article XXIV of the General Agreement on Tariffs and Trade (GATT).

Although studies have been conducted on the two main variables of this paper inclusive of other variables, this study bridged the literature gap by being the first to examine the impact of corruption in the presence of economic and financial institutional factors. The ease of doing business by entrepreneurs and corporations is determined by how friendly and favourable is the business and the economic environment. The existence of economic uncertainty and unfriendly access to financial resources in time of need will make doing business difficult and will in turn negatively affect the inflow of investment.

The rest of this study covers the literature review in section two, developing and testing the data (methodology) in section three, and the interpretation and explanation of the result in section four. The implications of the result for theory and practice provide the background for the conclusion and recommendation in section five.

\section{Literature Review}

Evaluation of the ease of doing business is essential for managers because it provides a yardstick for the measure of risks and set-up costs (Mongay and Filipescu, 2012). Availability of good institutions is an indicator of economic freedom; geography, market size, and labour costs are also determinants of the inward flow of foreign direct investment and its magnitude (Júlio, Pinheiro-Alves, and Tavares, 2013). The ease of doing business score, index, and ranking are provided by the World Bank for 264 countries for the year 2017. For instance, 119 economies of the world carried out 264 business reforms in 2017 in order to encourage investment, reduce unemployment, and increase competition. This amounts to 3,188 business reforms between 2003 and 2018 for ease of doing business for domestic small and medium enterprises around the world (World Bank, 2018).

The reform distribution shows that developing countries introduced 206 reforms ( $78 \%$ of the total reforms), sub-Saharan Africa achieved a second consecutive annual record with 38 reforms (14\%), and South Asia introduced a record of 20 reforms ( $8 \%)$. Improving access to credit and registration of business were the major focus of these reforms (38 reforms each), while 33 of the reforms focused on facilitating cross-border trade. Based on reforms undertaken, Nigeria was - for 
the first time in 2018 - among the first 10 reformers including El Salvador, India, Malawi, Thailand, Brunei Darussalam (for a second consecutive year), Kosovo, Uzbekistan, Zambia, and Djibouti. 186 countries out of the 190 monitored by the World Bank introduced business reforms in the period of 2003-2018, with 626 reforms targeted at easing requirements for starting a business.

There is a direct connection between corruption and the rent-seeking attitude of individuals in positions of administrative leadership or authority (Shleifer and Vishny, 1993; Jain, 2001; Hillman, 2013). When higher rents are connected with abuse of position of administrative leadership or authority, the total illegal disbursements and penalties associated with such abuse of power lead to corruption (Mongay and Filipescu, 2012). Mongay and Filipescu (2012) posited that the roles of the government as well as historical and geographical factors are the main elements that are important in the study of corruption. Corruption negatively affects cross-border investment and consequently reduces the volume of foreign direct investment in such regions (Smarzynska and Wei, 2002; Júlio, Pinheiro-Alves, and Tavares, 2013).

The size and scope of the government institutions and organizations to promote bribe incites and positively affects corruption (Calderon, Alvarez-Arce, and Mayoral, 2009; Doucouliagos and Ulubasoglu, 2008), while geographical factors can mitigate against corruption (Goel and Nelson, 2010). The absence or low level of corruption in developed countries encourages innovation, and the citizens becomes successful entrepreneurs, while developing countries experience growth through small business entrepreneurs as a result of the high level of corruption which discourages the establishment of big corporations (Mitchell and Campbell, 2009).

Theoretically, the rent-seeking theory was one of the various economic instruments that model corruption. Rent seeking as a theory was developed by Tullock (1967), who explained the effects of rent seeking and lobbying on public policy. Rent refers to the divisions of income such as profit and wage. Similar studies, such as Smith (1981), Buchanan (1980), Krueger (1974), or Posner (1975), do not provide a comprehensive analytical framework for explaining the social costs of lobbying. Rent seeking has shown that lobbying activities using transfers of resources encourage the diversion of such resources away from win-win activities and towards zero profits or even losses, which lead to social costs. The existence of positive opportunity costs of the transfer elsewhere in the economy gives rise to the social costs with respect to engaging in win-win activities. The rent seeking theory does not denounce traditional profit seeking or entrepreneurship in the competitive model. Profit seeking is productive as it creates values, such as new products, allocation of resources for optimal uses, etc., while rent seeking is nonproductive as it extinguishes through wastage of valuable resources.

The low costs of rent seeking in relation to the gains is the clear paradox of Tullock (1967): rent seekers in need of favours do bribe administrators at a cost 
lower than the value of the favour. Critics of the concept point out that, in practice, there may be difficulties distinguishing between beneficial profit seeking and detrimental rent seeking. This is because the rent seeking theory is basically indifference towards corruption as a form of rent seeking (Lambsdorff, 2002).

There is a vast number of empirical studies on the effects of corruption on economic indicators such as economic growth, foreign direct investment, capital market, and ease of doing business (Anoruo and Braha, 2015; Omodero, 2019; Karama, 2014; Bonga and Mahuni, 2018; Mongay and Filipescu, 2012; Nageri, Nageri, and Amin, 2015; Bounoua and Matallah, 2014). Findings of the studies are inconclusive, and the debate on the impact of corruption still rages on. This study is a contribution to the debate in the literature from the West African perspective. Corruption constitutes an impediment for investment by companies from less corrupt countries in a corrupt country, while corruption is not an impediment to investment for multinational companies from corrupt countries in similarly corrupt countries (Wei, 2000; Wu, 2006).

The study of Nageri, Nageri, and Amin (2015) used vector error correction mechanism to examine the joint impact of corruption and capital market on economic growth; findings suggest that there is short-run gain of corruption but a long-term pain. Omodero (2019) used multiple OLS regression to investigate the effect of corruption on foreign direct investment, and findings suggest the need to establish a strong institutional and legal system to fight the prevailing negative impact of corruption. Quazi, Vemuri, and Soliman (2014) studied the impact of corruption on FDI in 53 African countries from 1995 to 2012 using the generalized method of moments and concluded that corruption hastened foreign direct investment inflows in Africa.

Klapper, Laeven, and Rajan (2006) and Bruhn (2011) find that reduced entry cost led to increase in registered local businesses in Mexico and a number of new firms, while higher entry cost led to reduction in total factor productivity (Barseghyan 2008). Corcoran and Gillanders (2014) found that openness, the size of the domestic market, trade costs, and gross domestic product are significant determinants of FDI, while trading across borders as a component of ease of doing business is the most naturally attractive component.

Bonga and Mahuni (2018) assessed the impact of ease of doing business and corruption on the economic growth for Africa Free Trade Zones using panel data analysis and found that corruption and ease of doing business had significant impact on the bloc's growth, with prevailing individual differences of the countries. Gasanova, Medvedev, and Komotskiy (2017) investigated the impact of corruption on FDI inflows, and their findings suggest that the high level of corruption in the countries and unfavourable economic environment negatively affect FDI inflows. 


\section{Methodology}

Multiple regression technique was used for this study, using the sample period of 2004-2017. The data was acquired from the World Bank indicator and Transparency International for West African countries. The period was influenced by the fact that the data for ease of doing business were recorded from the year 2004 onwards, while the other explanatory variable data are available up to 2017 as at the time of conducting this research. The panel data analysis of the fixed and random effect model was used to estimate the parameters, and the most efficient model was selected after the unit root test was conducted on the data to avoid bogus result.

\subsection{Model Specification}

The model used for this research, in its functional form, is expressed as:

$\mathrm{EDB}=\mathrm{F}(\mathrm{CR}, \mathrm{COC}, \mathrm{INF}, \mathrm{LRS}, \mathrm{EDU}, \mathrm{GCF}, \mathrm{IMP}, \mathrm{EXP}, \mathrm{GDP}, \mathrm{POP})$

$\mathrm{EDB}=\mathrm{F}(\mathrm{CS}, \mathrm{COC}$, INF, LRS, EDU, GCF, IMP, EXP, GDP, POP),

where EDB is Ease of doing business score, CR is Corruption rank, CS is Corruption score, COC is Control of corruption, INF is Inflation rate, LRS is Lending rate spread, EDU is Education (skill level), GCF is Gross capital formation, IMP is Import, EXP is Export, GDP is Gross domestic product, and POP is Population.

The econometric form is written as:

$$
\begin{aligned}
& \mathrm{EDB}_{i t}=\beta_{1}+\beta_{2} \mathrm{CR}_{i t}+\beta_{3} \mathrm{COC}_{i t}+\beta_{4} \mathrm{INF}_{i t}+\beta_{5} \mathrm{LRS}_{i t}+\beta_{6} \mathrm{EDU}_{i t}+\beta_{7} \mathrm{GCF}_{i t}+ \\
& \beta_{8} \mathrm{IMP}_{i t}+\beta_{9} \mathrm{EXP}_{i t}+\beta_{10} \mathrm{GDP}_{i t}+\beta_{11} \mathrm{POP}_{i t}+\varepsilon_{i t 1} \\
& \mathrm{EDB}_{i t}=\beta_{1}+\beta_{2} \mathrm{CS}_{i t}+\beta_{3} \mathrm{COC}_{i t}+\beta_{3} \mathrm{INF}_{i t}+\beta_{4} \mathrm{LRS}_{i t}+\beta_{6} \mathrm{EDU}_{i t}+\beta_{7} \mathrm{GCF}_{i t}+ \\
& \beta_{8} \mathrm{IMP}_{i t}+\beta_{9} \mathrm{EXP}_{i t}+\beta_{10} \mathrm{GDP}_{i t}+\beta_{11} \mathrm{POP}_{i t}+\varepsilon_{i t 2} \\
& \mathrm{i}=1,2,3 \ldots \ldots .16 \text { countries, }=2004-2017,
\end{aligned}
$$

where $\mathrm{i}$ is the $\mathrm{i}^{\text {th }}$ country and $\mathrm{t}$ is the period for the variables defined above.

The employed quantitative tools of data analysis are the panel data unit root test, fixed and random model, and the Hausman test to determine the most efficient estimate between the fixed and random effect models. Table 1 consists of the variables used in the study, the description of the variables, and the source of the data used as proxy for the variables. 
Table 1. Description of variables

\begin{tabular}{|c|c|c|}
\hline Variables & Description & Source \\
\hline EDB & $\begin{array}{l}\text { Ease of Doing Business Score: the regulatory } \\
\text { performance score of the indicators of ease of doing } \\
\text { business in a country. } \\
\text { The score ranges from } 0 \text { (worst regulatory } \\
\text { performance) to } 100 \text { (best regulatory performance). }\end{array}$ & $\begin{array}{l}\text { WB: Doing } \\
\text { Business }\end{array}$ \\
\hline CR & $\begin{array}{l}\text { Corruption Rank: the least relative corruption } \\
\text { position of a particular country among other } \\
\text { countries evaluated during the period by the } \\
\text { corruption perception index. The higher the rank, } \\
\text { the higher the perceived corruption in the country. }\end{array}$ & $\begin{array}{l}\text { TI: Corruption } \\
\text { Perception Index }\end{array}$ \\
\hline CS & $\begin{array}{l}\text { Corruption Score: the corruption perception index } \\
\text { score of a particular country ranges from } 0 \text { (very } \\
\text { corrupt) to } 100 \text { (very clean). }\end{array}$ & $\begin{array}{l}\text { TI: Corruption } \\
\text { Perception Index }\end{array}$ \\
\hline COC & $\begin{array}{l}\text { Control of Corruption: the estimate of a country's } \\
\text { score of the aggregate indicator of private gain and } \\
\text { interest acquired through public power and élites } \\
\text { in forms of petty and grand corruption. It ranges } \\
\text { from approximately - } 2.5 \text { (bad practice of corruption } \\
\text { control) to } 2.5 \text { (best practice of corruption control). }\end{array}$ & $\begin{array}{l}\text { WB: Worldwide } \\
\text { Governance } \\
\text { Indicators }\end{array}$ \\
\hline INF & $\begin{array}{l}\text { Inflation: annual percentage change in the cost } \\
\text { of the basket of goods and services to an average } \\
\text { consumer at specified interval, consumer prices } \\
\text { (annual \%). }\end{array}$ & $\begin{array}{l}\text { WB: World } \\
\text { Development } \\
\text { Indicators }\end{array}$ \\
\hline LRS & $\begin{array}{l}\text { Lending Rate Spread: it is the interest rate charged } \\
\text { by banks on loans to private sector customers, } \\
\text { deducting interest rate paid by commercial or } \\
\text { similar banks for demand, time, or savings deposits } \\
\text { (lending rate minus deposit rate, \%). }\end{array}$ & $\begin{array}{l}\text { WB: World } \\
\text { Development } \\
\text { Indicators }\end{array}$ \\
\hline EDU & $\begin{array}{l}\text { Education: the expected years of schooling as a } \\
\text { measure of skill level. }\end{array}$ & $\begin{array}{l}\text { UNDP: Human } \\
\text { Development } \\
\text { Report }\end{array}$ \\
\hline GCF & $\begin{array}{l}\text { Gross Capital Formation: the additional } \\
\text { disbursements to the fixed assets of the economy } \\
\text { plus net changes in the level of inventories as a } \\
\text { percentage of Gross Domestic Product (GDP). }\end{array}$ & $\begin{array}{l}\text { WB: World } \\
\text { Development } \\
\text { Indicators }\end{array}$ \\
\hline
\end{tabular}




\begin{tabular}{lll}
\hline Variables & Description & Source \\
\hline IMP & $\begin{array}{l}\text { Imports of Goods and Services: the worth of goods } \\
\text { and services received by a country from the rest of } \\
\text { the world (minus employees' compensation and } \\
\text { investment income) as a percentage of GDP. }\end{array}$ & $\begin{array}{l}\text { WB: World } \\
\text { Development } \\
\text { Indicators }\end{array}$ \\
\hline EXP & $\begin{array}{l}\text { Exports of Goods and Services: the worth of all } \\
\text { goods and services provided by a country to the } \\
\text { rest of the world (minus investment income and } \\
\text { employees' compensation) as percentage of GDP. }\end{array}$ & $\begin{array}{l}\text { WB: World } \\
\text { Indicators }\end{array}$ \\
\hline GDP & $\begin{array}{l}\text { Gross Domestic Product Growth: the yearly } \\
\text { percentage growth of GDP at market prices based } \\
\text { on constant local currency. }\end{array}$ & $\begin{array}{l}\text { WB: World } \\
\text { Development } \\
\text { Indicators }\end{array}$ \\
\hline POP & $\begin{array}{l}\text { Population Density: the half-year population } \\
\text { divided by land area in square kilometres of a } \\
\text { country (people per square metre kilometre of land } \\
\text { area). }\end{array}$ & $\begin{array}{l}\text { WB: World } \\
\text { Development } \\
\text { Indicators }\end{array}$ \\
\hline
\end{tabular}

Notes: WB: World Bank, TI: Transparency International, UNDP: United Nations Development Programme

\section{Analysis and Presentation of Results}

This section provides the results and the interpretation of the results conducted on the data. Results were presented in tabular forms and were followed by interpretation.

Table 2 reveals positive mean for all the variables except control of corruption and that the standard deviation of EDB, CS, COC, EXP, LRS, INF, EDU, GCF, and GDP are low while that of CR, IMP, and POP are high. The Jarque-Bera statistics, which combines skewness and kurtosis as asymptotic normality of the variables, indicates a p-value of less than $5 \%$ except for EDU.

Table 3 shows the unit root test results for the variables used in the study. Results specify that all the variables except CS, LRS, EDU, and GDP have unit root at levels and, therefore, non-stationary with all the methods of unit root tests. The first difference $\{\mathrm{I}(1)\}$ of all the variables indicates the absence of unit root with the p-value of the unit root methods (Levin, Lin, Chu, Im, Pesaran, and Chin, augmented Dickey-Fuller, and Philips Perron) less than 5\%. This indicates that the data at first order (first difference) are suitable for regression analysis. 


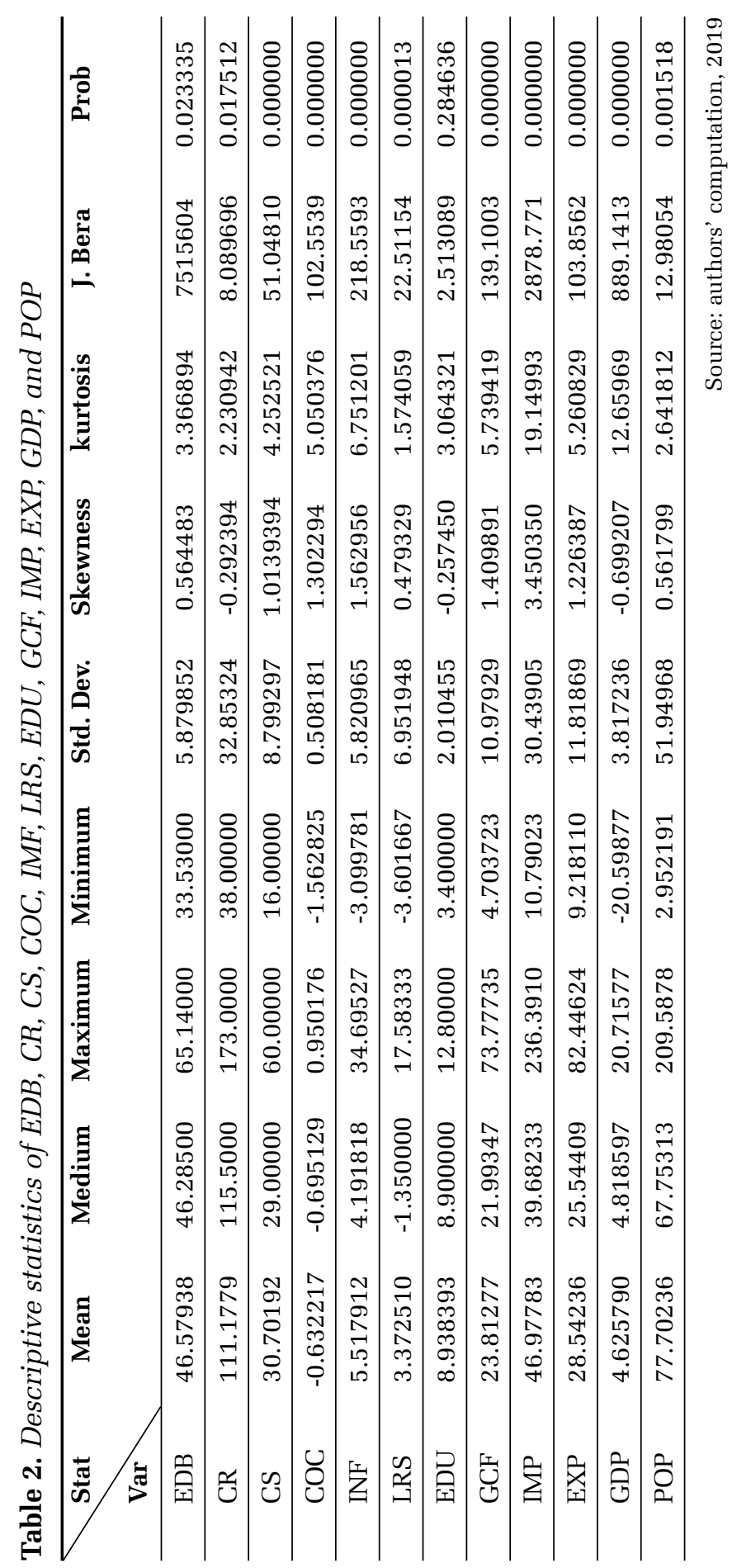




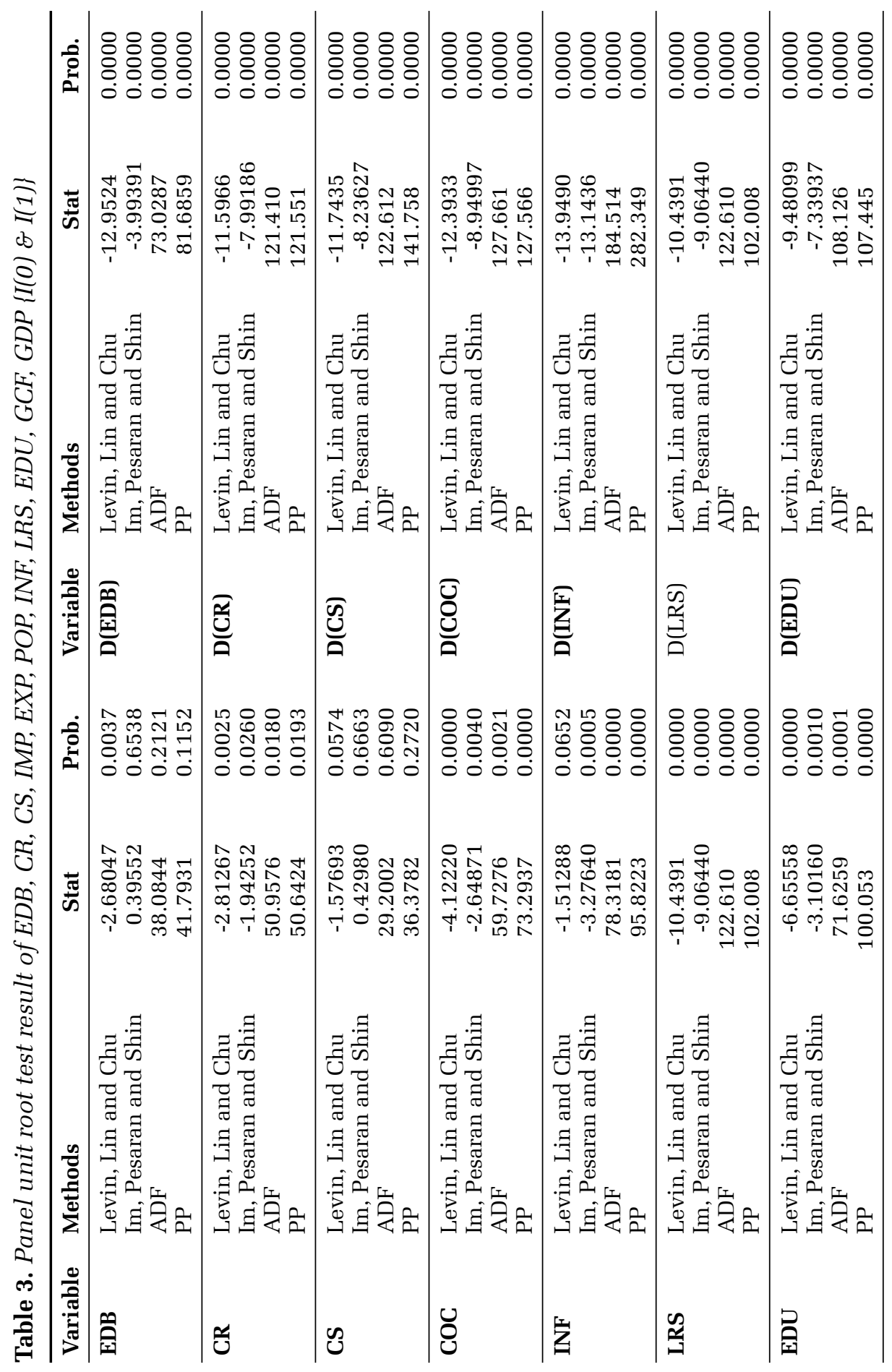




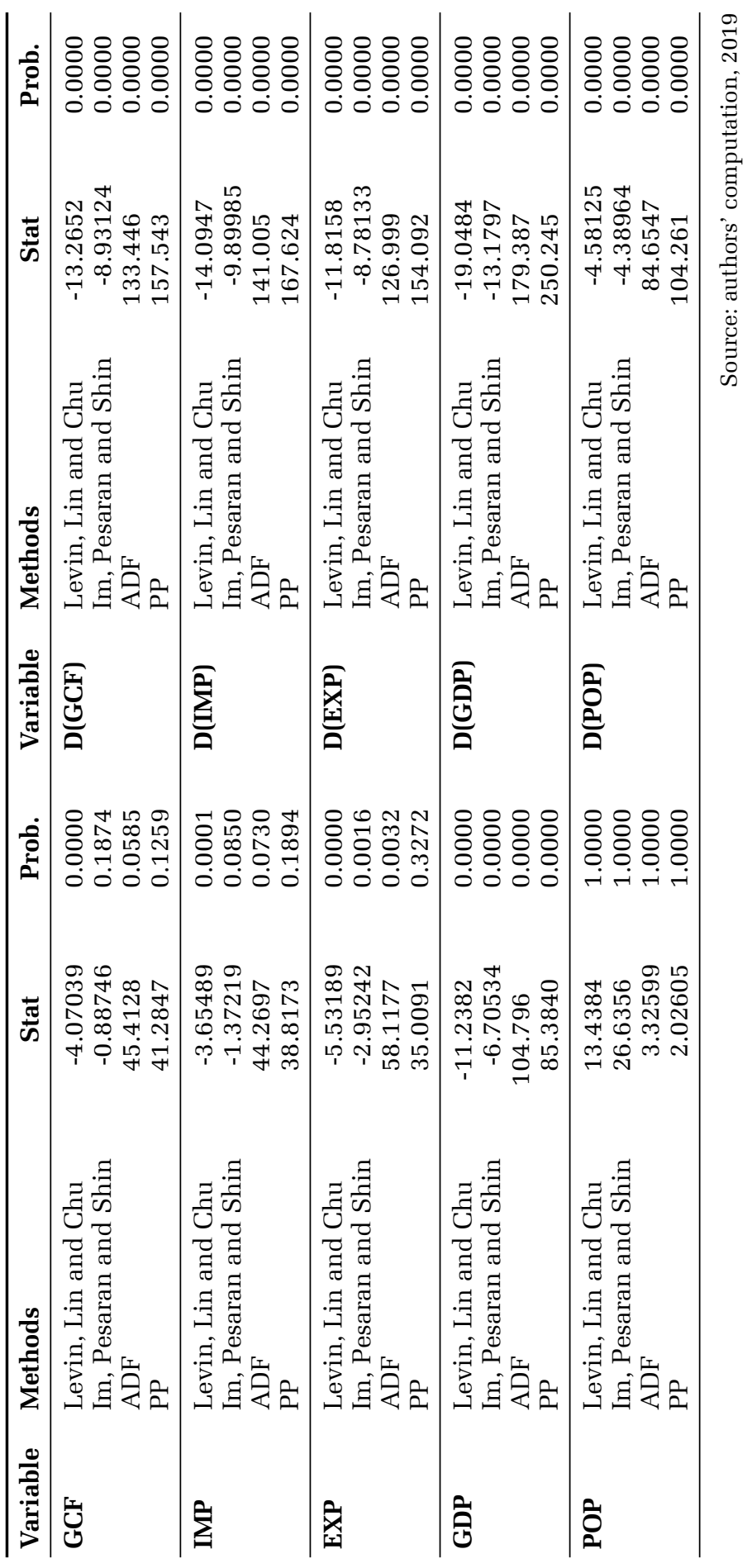


Table 4. Panel fixed effect and random effect models result for corruption rank

\begin{tabular}{|c|c|c|c|c|c|}
\hline \multicolumn{3}{|c|}{$\begin{array}{c}\text { Panel Fixed Effect Model } \\
\text { Dependent Variable: D(EDB) }\end{array}$} & \multicolumn{3}{|c|}{$\begin{array}{l}\text { Panel Random Effect Model } \\
\text { Dependent Variable: D(EDB) }\end{array}$} \\
\hline Variable & Coefficient & Prob. & Variable & Coefficient & Prob. \\
\hline $\mathrm{C}$ & 1.074945 & 0.8950 & $\mathrm{C}$ & 36.35647 & 0.0000 \\
\hline $\mathrm{D}(\mathrm{CR})$ & 0.003455 & 0.8914 & $\mathrm{D}(\mathrm{CR})$ & -0.043875 & 0.0279 \\
\hline $\mathrm{D}(\mathrm{COC})$ & 2.159644 & 0.2021 & $\mathrm{D}(\mathrm{COC})$ & 4.005950 & 0.0019 \\
\hline $\mathrm{D}(\mathrm{INF})$ & -0.167781 & 0.0865 & D(INF) & -0.226735 & 0.0159 \\
\hline D(LRS) & 0.917610 & 0.0003 & D(LRS) & 0.619732 & 0.0000 \\
\hline $\mathrm{D}(\mathrm{EDU})$ & 3.300663 & 0.0000 & $\mathrm{D}(\mathrm{EDU})$ & 2.268305 & 0.0000 \\
\hline D(GCF) & -0.077801 & 0.1764 & $\mathrm{D}(\mathrm{GCF})$ & -0.066465 & 0.1650 \\
\hline D(IMP) & -0.024431 & 0.6284 & D(IMP) & -0.088026 & 0.0175 \\
\hline $\mathrm{D}(\mathrm{EXP})$ & 0.068965 & 0.1897 & $\mathrm{D}(\mathrm{EXP})$ & 0.027979 & 0.5073 \\
\hline $\mathrm{D}(\mathrm{GDP})$ & 0.083660 & 0.1238 & $\mathrm{D}(\mathrm{GDP})$ & 0.058286 & 0.2455 \\
\hline $\mathrm{D}(\mathrm{POP})$ & 0.169032 & 0.0017 & $\mathrm{D}(\mathrm{POP})$ & -0.011724 & 0.5393 \\
\hline
\end{tabular}

The fixed effect model results in Table 4 indicate that LRS, EDU, and POP have positive and significant impact on EDB at $5 \%$, while INF is negatively significant at $10 \%$ level. CR, COC, EXP, and GDP are positive and insignificant, while GCF and IMP have negative and insignificant effect on EDB. The random effect model indicates that CR, INF, and IMP have significant negative impact on EDB, while COC, LRS, and EDU have significant positive impact on EDB. GCF and POP are negative and insignificant to EDB, but EXP and GDP are positive and insignificant to EDB.

Table 5. Hausman test results for corruption rank

Dependent Variable: D(EDB)

Independent Variables: D(CR), D(INF), D(LSR), D(EDU), D(GCF), D(IMP), D(EXP), $\mathrm{D}(\mathrm{GDP}), \mathrm{D}(\mathrm{POP})$

Test Summary

Chi-Sq. Stat.

Prob.

Cross-section random

8.629869

0.5676

Source: authors' computation, 2019

Table 5 shows the Hausman test results aiming to reveal the more efficient and consistent estimator between the fixed effect model and the random effect model for the corruption rank models. Results indicate that the null hypothesis (the random effect model is appropriate) cannot be rejected, as shown by the fact 
that the p-Value of 0.5676 is more than $5 \%$. This means that the random effect estimator is the consistent and most efficient model. This indicates that there is a common mean value for the intercept (EDB); in other words, there is a common mean value for EDB in West African countries.

Table 6. Panel fixed effect and random effect model results for corruption score

\begin{tabular}{ll}
\hline Panel Fixed Effect Model & Panel Random Effect Model \\
Dependent Variable: D(EDB) & Dependent Variable: D(EDB)
\end{tabular}

\begin{tabular}{lcclcc}
\hline Variable & Coefficient & Prob. & Variable & Coefficient & Prob. \\
\hline $\mathrm{C}$ & 5.128068 & 0.3933 & $\mathrm{C}$ & 27.69343 & 0.0000 \\
\hline $\mathrm{D}(\mathrm{CS})$ & 0.131619 & 0.0952 & $\mathrm{D}(\mathrm{CS})$ & 0.309652 & 0.0000 \\
\hline $\mathrm{D}(\mathrm{COC})$ & 2.259777 & 0.1749 & $\mathrm{D}(\mathrm{COC})$ & 3.113554 & 0.0121 \\
\hline $\mathrm{D}(\mathrm{INF})$ & -0.145665 & 0.1251 & $\mathrm{D}(\mathrm{INF})$ & -0.200097 & 0.0286 \\
\hline $\mathrm{D}(\mathrm{LRS})$ & 0.837552 & 0.0006 & $\mathrm{D}(\mathrm{LRS})$ & 0.592789 & 0.0000 \\
\hline $\mathrm{D}(\mathrm{EDU})$ & 2.869481 & 0.0000 & $\mathrm{D}(\mathrm{EDU})$ & 1.733873 & 0.0001 \\
\hline $\mathrm{D}(\mathrm{GCF})$ & -0.091323 & 0.1067 & $\mathrm{D}(\mathrm{GCF})$ & -0.075437 & 0.1094 \\
\hline $\mathrm{D}(\mathrm{IMP})$ & -0.023064 & 0.6420 & $\mathrm{D}(\mathrm{IMP})$ & -0.090906 & 0.0126 \\
\hline $\mathrm{D}(\mathrm{EXP})$ & 0.026293 & 0.6274 & $\mathrm{D}(\mathrm{EXP})$ & -0.017041 & 0.6889 \\
\hline $\mathrm{D}(\mathrm{GDP})$ & 0.085281 & 0.1107 & $\mathrm{D}(\mathrm{GDP})$ & 0.067564 & 0.1717 \\
\hline $\mathrm{D}(\mathrm{POP})$ & 0.140176 & 0.0104 & $\mathrm{D}(\mathrm{POP})$ & -0.013099 & 0.4832 \\
\hline
\end{tabular}

Source: authors' computation, 2019

Table 6 depicts the fixed and the random effect model results for corruption score, indicating that LRS and EDU are positive and statistically significant to EDB and GCF is negative and significant at $10 \%$ to EDB. In the fixed effect model, CS is positive and significant at $10 \%, \mathrm{POP}$ is positive and significant at $5 \%$, while COC is positive and insignificant to EDB. INF and IMP are negative and insignificant to EDB. INF and IMP are negatively insignificant to EDB. In the random effect model, CS and COC are positively significant to EDB, while INF and IMP are negatively significant to EDB. EXP and POP are negatively insignificant but GDP is positively insignificant to EDB.

This shows that increase in corruption score and control of corruption relative to other countries leads to increase in ease of doing business, meaning that the higher the corruption score and control of corruption (indicating reduced corruption practices), the better ease of doing business in West African countries. 
Table 7. Hausman test result for corruption score

\begin{tabular}{|c|c|c|}
\hline \multicolumn{3}{|c|}{$\begin{array}{l}\text { Dependent Variable: D(EDB) } \\
\text { Independent Variables: D(CS), D(INF), D(LSR), D(EDU), D(GCF), D(IMP), D(EXP), } \\
\text { D(GDP), D(POP) }\end{array}$} \\
\hline Test Summary & Chi-Sq. Stat. & Prob. \\
\hline Cross-section random & 7.433049 & 0.6840 \\
\hline
\end{tabular}

Source: authors' computation, 2019

Table 7 shows the Hausman test results aiming to reveal the more efficient and consistent estimator between the fixed effect model and the random effect model for the corruption score models. Results indicate that the null hypothesis (the random effect model is appropriate) cannot be rejected. This means that the random effect estimator is the consistent and more efficient model. This indicates that there is a common mean value for the intercept (EDB); in other words, there is a common mean value for EDB in West African countries.

In summary, corruption rank has significant negative effect on ease of doing business, while corruption score and control of corruption have a significantly positive effect on ease of doing business. This simply means that the more countries are perceived to be corrupt among other countries, the less easy is to start businesses in such countries, while the higher the perception score and control of corruption a country has, the easier doing business in such countries. This finding is in tandem with the findings of Mongay and Filipescu (2012), Nageri, Nageri, and Amin (2015), Bounoua and Matallah (2014), and Omodero (2019) but in disagreement with the findings of Gutierrez (2015), Quazi et al. (2014), and Bayar and Alakbarov (2016).

\section{Summary, Conclusions, and Recommendations}

This article analyses the effects of corruption as well as the economic and financial institutional factors on ease of doing business. It investigates the impact of corruption in the presence of gross domestic product, inflation, lending rate spread, education (skill level), gross capital formation, import, export, and population in terms of promoting ease of doing business. West Africa was used as an illustration; the methodology can be applied to any specific country to achieve country-specific results. The dataset comprises the sixteen (16) West African countries, covering the period of 2004-2017 due to data availability.

Unbalanced panel data analysis was employed as a result of non-availability of some data in the datasets. Panel data unit root test was conducted, and the first difference of the dataset was found to have no unit root and thus was used for the analysis. The fixed effect and random effect models were estimated, and the 
most efficient model was found to be the random effect model using the Hausman test. Results indicate that the dataset has a common mean, and thus results are is applicable to the countries in the dataset.

Results indicate that corruption rank, inflation, and import have negative and significant effect on ease of doing business, while population, gross capital formation, and export have negative but insignificant effect on ease of doing business. Secondly, corruption score, control of corruption, lending rate spread, and education (skill level) all have positive and significant effect on ease of doing business, while export and gross domestic product have negative and insignificant effect on ease of doing business.

The study concludes that perceived bad corruption rank negatively affects ease of doing business, but corruption score and control of corruption positively affect ease of doing business in the presence of inflation, education (skill level), gross domestic product, lending rate spread, export, import, population, and gross capital formation. Lending rate spread and education (skill level) positively and significantly affect ease of doing business, while inflation and import negatively and significantly affect ease of doing business. Export and gross domestic product are positive but insignificant, while population and gross capital formation are negative and insignificant; however, this does not imply that no action needs to be taken but urges the formulation of policies to discourage corruption, high inflation, and importation and encourages increase in local production through gross domestic product, control of population, and gross capital formation in order to positively stimulate exportation and start-up businesses.

The study recommends that countries need to improve their corruption scores to reduce their ranking in the list of countries through control of corruption in order to encourage ease of doing business. Policy in ECOWAS countries must be effective to reduce importation and inflation, while gross domestic product should be encouraged through improved infrastructural facilities, such as investment in power supply or improved road networks, in order to encourage the establishment of new businesses. Despite the insignificantly positive and negative impact of export, gross capital formation, and population, they should not be left unaddressed. Hence, gross capital formation should be encouraged to ease doing business and production of excess to encourage exportation, while population growth should be controlled.

The study demonstrates the joint impact of corruption score, corruption rank, and control of corruption with economic and financial institutional factors as a means to promote ease of doing business, and it uses a methodology that, for a given country, recommends several possible economic and financial institutional reforms regarding their impact on ease of doing business. 


\section{References}

Ali, A. M.; Isse, H. S. (2003). Determinants of economic corruption: A cross-country comparison. Cato Journal 22(3): 449-469. (https://object.cato.org/sites/cato.org/ files/serials/files/cato-journal/2002/1/cj22n3-4.pdf).

Anoruo, E.; Braha, H. (2005). Corruption and economic growth: The African experience. Journal of Sustainable Development in Africa 7(1): 43-55. (www. ce.vizja.pl/en/download-pdf/volume/9/issue/1/id/386).

Asiedu, E.; Freeman, J. (2009). The effect of corruption on investment growth: Evidence from firms in Latin America, sub-Saharan Africa, and Transition Countries. Review of Development Economics 13(2): 200-14. (https://doi.org/10.1111/ j.1467-9361.2009.00507.x).

Barseghyan, L. (2008). Entry costs and cross-country differences in productivity and output. Journal of Economic Growth 13(2): 145-167. (https://dx.doi.org/10.1007/ s10887-008-9026-6).

Bayar, Y.; Alakbarov, N. (2016). Corruption and foreign direct investment inflows in emerging market economies. ECOFORUM 5(2): 303-308. (www.ecoforumjournal. ro/index.php/eco/article/download/431/270).

Bonga, W. G.; Mahuni, K. (2018). Assessing the impact of ease of doing business and corruption on economic growth for Africa Free Trade Zone (AFTZ) member states. MPRA Paper 88932, University Library of Munich, Germany.

Bounoua, C.; Matallah, S. (2014). Corruption and economic growth: Empirical evidence from Algeria. International Journal of Innovation and Applied Studies 8(3): 927-946. (https://pdfs.semanticscholar.org/d959/635b9911e3c2591b43 00e91aa7922f78febf.pdf).

Bruhn, M. (2011). License to sell: The effect of business registration reform on entrepreneurial activity in Mexico. The Review of Economics and Statistics 93(1): 382-386. (https://dx.doi.org/10.1162/REST_a_00059).

Buchanan, J. (1980). Rent seeking and profit seeking. In: Buchanan, J. M.; Tollison, R. D.; Tullock, G. (eds.), Towards a theory of the rent-seeking society. College Station, TX: Texas A\&M Press. 3-15. Reprinted in R. D. Congleton: Hillman, A. L.; Konrad, K. A. (eds.). (2008). Forty years of research on rent seeking 1-The theory of rent seeking. Heidelberg: Springer. 55-67.

Calderon, R.; Alvarez-Arce, J.; Mayoral, S. (2009). Corporation as a crucial ally against corruption. Journal of Business Ethics 87: 319-32. (http://.dx.doi. org/10.1007/s10551-008-9796-y).

Doucouliagos, H.; Ulubasoglu, M. A. (2008). Democracy and economic growth: A meta-analysis. American Journal of Political Science 52(1): 61-83. (https:// dx.doi.org/10.1111/j.1540-5907.2007.00299.x). 
Gasanova, A.; Medvedev, A. N.; Komotskiy, E. I. (2017). The assessment of corruption impact on the inflow of foreign direct investment. AIP Conference Proceedings 1836. (https://dx.doi.org/10.1063/1.4981951).

Goel, R. K.; Nelson, M. A. (2010). Causes of corruption: History, geography and government. Journal of Policy Modeling 32(4): 433-447. (https://dx.doi. org/10.1016/j.jpolmod.2010.05.004).

Gutierrez, K. P. (2015). The effect of corruption on FDI in Argentina: Has corruption acted as a negative determinant discouraging FDI? Universitat Autònoma de Barcelona. 1-29. (https://core.ac.uk/download/pdf/78527856.pdf).

Hillman, A. L. (2013). Rent seeking. In: Reksulak, M.; Razzolini, L.; Shughart, W. F. I. I. (eds.), The Elgar companion to public choice. $2^{\text {nd }}$ ed.. Cheltenham: Edward Elgar. 307-330.

Jain, A. K. (2001). Corruption: A review. Journal of Economic Surveys 15(1): 71-121. (https://dx.doi.org/10.1111/1467-6419.00133).

Jayasuriya, D. (2011). Improvements in the World Bank's ease of doing business rankings: Do they translate into greater foreign direct investment inflows? Development Policy Centre Discussion Paper 8. (http://dx.doi.org/10.2139/ ssrn.2040543).

Júlio, P.; Pinheiro-Alves, R.; Tavares, J. (2013). Foreign direct investment and institutional reform: Evidence and an application to Portugal. Portuguese Economic Journal 12(3): 215-250. (http://dx.doi.org/10.1007/s10258-013-0093-z).

Karama, D. (2014). Ease of doing business: Emphasis on corruption and rule of law. MPRA Paper 58662. University Library of Munich, Germany.

Kenny, C. (2009). Measuring corruption in infrastructure: Evidence from transition and developing countries. Journal of Development Studies 45(3): 314-332. (https://dx.doi.org/10.1080/00220380802265066).

Klapper, L.; Laeven, L.; Rajan, R. (2006). Entry regulation as a barrier to entrepreneurship. Journal of Financial Economics 82(3): 591-629. (http://dx.doi. org/10.1016/j.jfineco.2005.09.006).

Krueger, A. O. (1974). The political economy of the rent-seeking society. American Economic Review 137(2): 333-338. (http://cameroneconomics.com/kreuger\%20 1974.pdf).

Lambsdorff, J. G. (2002). Corruption and rent-seeking. Public Choice 113: 97-125. (https://dx.doi.org/10.1023/A:1020320327526).

Mitchell, D. T.; Campbell, N. D. (2009). Corruption's effect on business venturing within the United States. American Journal of Economics \& Sociology 68(5): 1135-1152. (https://dx.doi.org/10.1111/j.1536-7150.2009.00665.x).

Mongay, J.; Filipescu, D. A. (2012). Are corruption and ease of doing business correlated? An analysis of 172 nations. In: Harris, S.; Kuivalainen, O.; Stoyanova, V. (eds.), International business. The Academy of International Business. Palgrave Macmillan, London. (https://link.springer.com/chapter/10.1057/9781137007742_2). 
Nageri, K. I.; Nageri, S. I.; Amin, A. (2015). The joint impact of stock market and corruption on economic growth and development in Nigeria: Evidence from cointegration and VECM analysis. Serbian Journal of Management 10(2): 189-200. (https://scindeks-clanci.ceon.rs/data/pdf/1452-4864/2015/145248641502189 N.pdf).

National Bureau of Statistics (2017). National corruption survey: Corruption in Nigeria - Bribery as experienced by the population. Vol. 2.

Omodero, C. O. (2019). Effect of corruption on foreign direct investment inflows in Nigeria. Studia Universitatis “Vasile Goldis” Arad. Economics Series 29: 54-66.

Posner, R. A. (1975). The social cost of monopoly and regulation. Journal of Political Economy 83: 807-827. Reprinted in: R. D. Congleton, Hillman, A. L.; Konrad, K. A. (eds.). (2008). Forty years of research on rent seeking 2-Applications: Rent seeking in practice. Heidelberg: Springer. 45-65.

Quazi, R.; Vemuri, V.; Soliman, M. (2014). Impact of corruption on foreign direct investment in Africa. International Business Research 7(4): 1-10. (http://dx.doi. org/10.5539/ibr.v7n4p1).

Shleifer, A.; Vishny, R. W. (1993). Corruption. Quarterly Journal of Economics 108: 599-618. (https://projects.iq.harvard.edu/gov2126/files/shleifer_and_vishy.pdf).

Smarzynska, B. K.; Wei, S. (2002). Corruption and cross-border investment: Firmlevel evidence. Working Paper Series 494. William Davidson Institute.

Smith, B. C. (1981). Control in British government: A problem of accountability. Policy Studies Journal 9(8): 1163-1174. (https://dx.doi.org/10.1111/j.1541-0072.1981. tb01229.x).

Sunkanmi, O. A.; Isola, A. L. (2014). Corruption and economic growth in Nigeria. Journal of Economics and Sustainable Development 5(6): 45-56. (https://www. iiste.org/Journals/index.php/JEDS/article/view/11932).

The World Bank. Doing Business. (http://www.doingbusiness.org/en/methodology).

World Development Indicators. (https://databank.worldbank.org/source/worlddevelopment-indicators).

Worldwide Governance Indicators. (https://datacatalog.worldbank.org/dataset/ worldwide-governance-indicators).

Transparency International. Corruption Perception Index. (https://www.transparency. org/en/cpi\#).

Tullock, G. (1967). The welfare cost of tariffs, monopolies, and theft. Western Economic Journal 5: 224-232. Reprinted in: R. D. Congleton, Hillman, A. L.; Konrad, K. A. (eds.). (2008). Forty years of research on rent seeking 2Applications: Rent seeking in practice. Heidelberg: Springer. 45-53.

United Nations Development Programme. Human Development Report. (http:// hdr.undp.org/en/content/expected-years-schooling-children-years).

Wei, S. (2000). How taxing is corruption on international investors? Review of Economics and Statistics 82(1): 1-11. (https://dx.doi.org/10.1162/003465300558533). 
World Bank. (2018). Doing business 2018: Reforming to create job. A World Bank Group Flagship Report, $15^{\text {th }}$ edition.

Wu, S. (2006). Corruption and cross-border investment by multinational firms. Journal of Comparative Economics 34(4): 839-856. (https://dx.doi.org/10.1016/j. jce.2006.08.007). 